\title{
Determinants of formation of aflatoxin-albumin adducts: a seven-township study in Taiwan
}

\author{
C-A Sun*,', D-M Wu', L-Y Wang' ${ }^{2}$, C-J Chen ${ }^{3}$, S-L You ${ }^{3}$ and RM Santella ${ }^{4}$ \\ 'School of Public Health, National Defense Medical Center, School of Public Health, No. I61, Section 6, Min-Chuan East Road, Taipei II4, Taiwan, Republic \\ of China; ${ }^{2}$ Institute of Aboriginal Health, Tzu Chi University, Hualien County 970, Taiwan, Republic of China; ${ }^{3}$ Graduate Institute of Epidemiology, College of \\ Public Health, National Taiwan University, Taipei 100, Taiwan, Republic of China; ${ }^{4}$ Division of Environmental Health Sciences, Mailman School of Public \\ Health, Columbia University, New York, NY 10032, USA
}

Dietary exposure to aflatoxins is one of the major risk factors for hepatocellular carcinoma. Individual susceptibility to aflatoxin-induced hepatocarcinogenesis may be modulated by both genetic and environmental factors affecting metabolism. A cross-sectional study was performed to evaluate determinants of the formation of aflatoxin covalently bound to albumin (AFB -albumin adducts). A total of 474 subjects who were free of liver cancer and cirrhosis and were initially selected as controls for previous case-control studies of aflatoxin-induced hepatocarcinogenesis in Taiwan, were employed in this study. Aflatoxin-albumin adducts were determined by competitive enzyme-linked immunosorbent assay, hepatitis B surface antigen and antibodies to hepatitis C virus by enzyme immunoassay, as well as genotypes of glutathione S-transferase MI-I and TI-I by polymerase chain reaction. The detection rate of $A F B_{1}$-albumin adducts was significantly higher in males (42.5\%) than in females (21.6\%) (multivariate-adjusted odds ratio=2.6, 95\% confidence interval=1.4-5.0). The formation of detectable albumin adducts was moderately higher in hepatitis B surface antigen carriers (42.8\%) than in non-carriers (36.6\%) (multivariate-adjusted odds ratio $=1.4,95 \%$ confidence interval=1.0-2.1). In addition, the detection rate of $A F B_{1}$-albumin adducts tended to increase with the increasing number of null genotypes of glutathione S-transferase MI-I and glutathione Stransferase $\mathrm{TI}-\mathrm{I}$. In conclusion, this cross-sectional study has assessed the relative contributions of environmental exposure and host susceptibility factors in the formation of $\mathrm{AFB}_{1}$-albumin adducts in a well characterised Chinese adult population. This study further emphasises the necessity to reduce aflatoxin exposure in people living in an area endemic for chronic hepatitis B virus infection.

British Journal of Cancer (2002) 87, 966 -970. doi:I0.1038/sj.bjc.6600584 www.bjcancer.com (C) 2002 Cancer Research UK

Keywords: aflatoxin-albumin adducts; glutathione S-transferase MI-I; glutathione S-transferase TI-I; hepatitis B surface antigen

Pervious studies have indicated that hepatocellular carcinoma (HCC) is of multifactorial origin with both viral and chemical carcinogens involved in the multistage process. Although chronic infection with hepatitis $\mathrm{B}$ virus (HBV) is now regarded as the major cause of HCC in high-incidence areas (Yeh et al, 1989; Chen et al, 1991; Ryder et al, 1992), ingestion of aflatoxin $\mathrm{B}_{1}\left(\mathrm{AFB}_{1}\right)$ has also been implicated as another major contributor to risk (Yeh et al, 1989; Ross et al, 1992; Wang et al, 1996a,b). Many studies have confirmed that parent compound $\mathrm{AFB}_{1}$ is converted to its carcinogenic forms through metabolism by members of the endogenous cytochrome P-450 enzyme superfamily to reactive 8,9-epoxide metabolites, which can covalently interact with cellular DNA and proteins (International Agency for Research on Cancer, 1992; Gallagher et al, 1994; Guengerich et al, 1998). Among the major epoxide-derived macromolecular adducts identified, the $\mathrm{AFB}_{1}$-albumin adduct correlates well with other aflatoxin measurements and provides a cumulative measure of exposure over several months in humans (Wild et al, 1986; Gan et al, 1988).

Accumulating evidence indicates that susceptibility to aflatoxinrelated HCC may be modulated by inter-individual differences in

*Correspondence: C-A Sun; E-mail: sunca@ndmctsgh.edu.tw Received 27 May 2002; revised 31 July 2002; accepted 7 August 2002 metabolism (McGlynn et al, 1995; Chen et al, 1996b; Sun et al, 2001). Both epidemiological and experimental studies have demonstrated a synergistic interaction between chronic HBV infection and aflatoxin exposure in the development of HCC (Ross et al, 1992; Wang et al, 1996a; Sylla et al, 1999). Taken together, the degree that $\mathrm{AFB}_{1}$ contributes to risk of HCC may be influenced by both genetic and environmental factors. Thus, we performed a cross-sectional study of 474 control subjects enrolled in previous nested casecontrol study of susceptibility to aflatoxin-related HCC (Wang et al, 1996b; Sun et al, 2001) to evaluate the correlations of multiple HCC enviromental and genetic susceptibility risk factors with the formation of $\mathrm{AFB}_{1}$-albumin adducts in the peripheral blood.

\section{MATERIALS AND METHODS}

\section{Study subjects}

From July 1990 through June 1992, a community-based two-stage liver cancer screening programme was carried out in seven townships in Taiwan. The cohort characteristics and methods of screening and follow-up have been described previously (Wang et al, 1996b; Sun et al, 2001). Briefly, in the two-stage screening programme, study subjects aged 30 to 64 years were first screened by serological markers, including hepatitis B surface antigen 
(HBsAg), antibodies to hepatitis $\mathrm{C}$ virus (anti-HCV), alanine transaminase (ALT), aspartate transaminase (AST), and $\alpha$-fetoprotein (AFP). HBsAg, anti-HCV, and AFP were tested by enzyme immunoassay using commercial kits (Abbott Laboratories, North Chicago, IL, USA), while both ALT and AST levels were determined by serum chemistry autoanalyzer (Hitachi Model 736; Hitachi Co., Tokyo, Japan) using commercial reagents (Biomerieux, Mercy I'Etoile, France). Any subject who had a positive status of HBsAg or anti-HCV, an elevated level of ALT (45 IU/ $\mathrm{L})$, AST $\left(40 \mathrm{IU} \mathrm{L}^{-1}\right)$, or AFP $\left(20 \mathrm{ng} \mathrm{ml}^{-1}\right)$, or a family history of HCC or liver cirrhosis among first degree relatives was referred for the second-stage screening by upper abdominal ultrasonography. The abdominal ultrasonography was performed by boardcertified gastroenterologists who were well experienced in ultrasonographic examinations using Toshiba SAL-38B and SSA-240A ultrasonographic apparatus with $3.75 \mathrm{MHZ}$ real-time linear and sector probes (Toshiba, Japan).

All participants were personally interviewed based on a structured questionnaire at recruitment. Blood samples were collected from each study subject. Aliquots of serum, buffy coat, plasma, and red blood cells were separated and stored at $-70^{\circ} \mathrm{C}$. Specimens were transported in dry ice to the central laboratory at the National Taiwan University and were kept in deep freezers until examination. All study subjects gave informed consent for both the interview and blood collection. In addition, anonymity of study subjects was maintained by the numerical coding of questionnaires and blood samples. This community-based cancer screening project was supported and approved by Department of Health, Executive Yuan.

The present study is concerned with 474 subjects who were initially selected as controls for previous nested case-control studies of aflatoxin-related hepatocarcinogenesis (Wang et al, 1996b; Sun et $a l, 2001)$. These individuals were not affected with HCC or cirrhosis through follow-up period. In fact, data used in the present study were obtained by mining of the original data set from these previous nested case-control studies.

\section{$\mathrm{AFB}_{1}$-albumin adducts in serum}

An enzyme-linked immunosorbent assay was used to determine the level of $\mathrm{AFB}_{1}$-albumin adducts in serum as previously described (Wang et al, 1996a; Sun et al, 2001). This assay had 50\% inhibition of antiserum binding at $10-20 \mathrm{fmol} \mathrm{AFB}_{1}$ adduct per well. The limit of sensitivity (20\% inhibition) when assaying the equivalent of $200 \mu \mathrm{g}$ albumin per well was $0.01 \mathrm{fmol} \mu \mathrm{g}^{-1}$. Samples were assayed by duplicate analysis in duplicate wells. Samples with $<20 \%$ inhibition were considered non-detectable. Two control samples were analysed with each batch of sera, a pooled sample of plasma from non-smoking US subjects and a positive control of serum from a rat treated with $1.5 \mathrm{mg} \mathrm{AFB}_{1}$.

\section{GSTM1-1 and GSTT1-1 genotypes}

GSTM1-1 genotyping for gene deletion was performed by PCR amplification with primers for exons 6 and 7, which produced a $210 \mathrm{bp}$ band, according to the method of Bell et al (1993). GSTT1-1 genotype was determined using the technique of Pemble et al (1994), with the modification that $\beta$-globin primers were added to the PCR.

\section{Statistical methods}

Because it was not considered appropriate to assign a value to the undetectable serum level of AFB1-albumin adducts, the adducts level was analysed as a binary rather than continuous variable. Odds ratios (OR) and their 95\% confidence intervals (CI), which were derived from logistic regression models, were used to indicate the magnitude of the associations between formation of $\mathrm{AFB}_{1}$-albumin adducts and various variables. In addition, months of year for blood sample collection were grouped into four seasons in order to evaluate seasonal variations in the detectable levels of $\mathrm{AFB}_{1}$-albumin adducts. All analyses were performed with SAS software (SAS Institute, Cary, NC, USA) and all $P$ values for tests of statistical significance were based on two-tailed probability.

\section{RESULTS}

The demographic data concerning the study subjects and the relationship of the positivity of $\mathrm{AFB}_{1}$-albumin adducts with these demographic characteristics are described in Table 1 . There were no significant variation in detection rate of $\mathrm{AFB}_{1}$-albumin adducts among study townships (ranging from 33.3 to $47.5 \%$ ), seasonality of sample collection (ranging from 36.8 to $43.0 \%$ ) and age groups (ranging from 26.9 to $40.6 \%$ ). In contrast, males had significantly higher detection rate of $\mathrm{AFB}_{1}$-albumin adducts than females (42.5 vs $21.6 \%$ ) with an odds ratio (OR) of 2.7 (95\% CI=1.5-5.0).

Results with regard to the detection rate of $\mathrm{AFB}_{1}$-albumin adducts in relation to multiple HCC risk factors are summarised in Table 2. $\mathrm{AFB}_{1}$-albumin adducts were detectable in $42.8 \%$ (86 of 201) of HBsAg carriers and $36.6 \%$ (100 of 273) of HBsAg non-carriers. The difference in the detection rate was moderately significant between the two groups $(\mathrm{OR}=1.3,95 \% \mathrm{CI}=1.0-1.9)$. This detection rate was higher in study subjects who smoked cigarettes $(43.8 \%)$ than in those who never smoked cigarettes $(35.1 \%)$, with a moderately significant $\mathrm{OR}$ of $1.4(95 \% \mathrm{CI}=1.0-2.1)$. In addition, there were also moderately significant differences in the adduct detection rate depending on GSTM1-1 and GSTT1-1 genotypes; the detection rate was higher in individuals with either GSTM1-1 null (43.0\%) or GSTT1-1 null (44.2\%) genotype than in those with GSTM1-1 (36.4\%) or GSTT1-1 (35.9\%) present. The $\mathrm{OR}$ of detectable $\mathrm{AFB}_{1}$-albumin adducts associated with GSTM1-1 or GSTT1-1 null genotype was 1.3 (95\% CI=1.0-1.9) and $1.4(95 \% \mathrm{CI}=1.0-2.0)$, respectively. On the other hand, the detection rate was lower in anti-HCV-positive subjects $(30.6 \%)$ than negative subjects $(41.6 \%)(\mathrm{OR}=0.7,95 \% \mathrm{CI}=0.3-1.3)$. There was again a slightly lower detection rate in individuals who consumed alcohol $(36.2 \%)$ than in those who never drank alcohol (39.9\%).

The effect of a combination of GSTM1-1 and GSTT1-1 genotypes on the detectable adduct levels was then analysed and stratified by $\mathrm{HBsAg}$ status. In this case the positivity of $\mathrm{AFB}_{1}$-albumin adducts tended to increase with increasing number of the null genotype of GSTM1-1 and GSTT1-1 in both the HBsAg carrier and non-carrier groups, albeit the trend was statistically non-significant (Table 3).

Results of logistic regression analysis of multiple factors associated with the positivity of $\mathrm{AFB}_{1}$-albumin adducts are shown in Table 4. After multivariate adjustment, male gender and positive HBsAg status was still significantly associated with positivity of $\mathrm{AFB}_{1}$-albumin adducts (for males: adjusted $\mathrm{OR}=2.6, \quad 95 \%$ $\mathrm{CI}=1.4-5.0$; for HBsAg carriers: adjusted $\mathrm{OR}=1.4,95 \% \mathrm{CI}=1.0-$ 2.1). Whereas, no significant association with detectable $\mathrm{AFB}_{1^{-}}$ albumin adduct levels was observed for age, anti-HCV positive status, habits of cigarette smoking and alcohol intake, and the null genotype of GSTM1-1 and GSTT1-1.

\section{DISCUSSION}

Data from human epidemiological studies have demonstrated that exposure to $\mathrm{AFB}_{1}$ is one of the major risk factors in the multifactorial etiology of HCC (Ross et al, 1992; McGlynn et al, 1995; Chen et al, 1996a,b; Wang et al, 1996b; Sun et al, 2001). Many studies have further confirmed that the toxic and carcinogenic effects of the aflatoxins are manifested only after metabolism by members 
Table I Baseline characteristics of study subjects and in relation to the detection rate of $\mathrm{AFB}_{1}$-albumin adducts

\begin{tabular}{|c|c|c|c|c|}
\hline \multirow[b]{2}{*}{ Variable } & \multirow[b]{2}{*}{ Group } & \multirow[b]{2}{*}{ No. } & \multicolumn{2}{|c|}{ AFB $_{1}$-albumin adducts } \\
\hline & & & $\begin{array}{c}\text { Detection rate } \\
\text { (\%) }\end{array}$ & $\begin{array}{l}\text { Odds ratio } \\
\left(95 \% \mathrm{Cl}^{\mathrm{a}}\right)\end{array}$ \\
\hline Sex & $\begin{array}{l}\text { Female } \\
\text { Male }\end{array}$ & $\begin{array}{r}74 \\
400\end{array}$ & $\begin{array}{l}21.6 \\
42.5\end{array}$ & $\begin{array}{l}1.0 \\
2.7(1.5-5.0)\end{array}$ \\
\hline Age & $\begin{array}{l}30-39 \\
40-49 \\
50-59 \\
60-64\end{array}$ & $\begin{array}{r}26 \\
102 \\
251 \\
95\end{array}$ & $\begin{array}{l}26.9 \\
40.2 \\
40.6 \\
37.9\end{array}$ & $\begin{array}{l}1.0 \\
1.8(0.7-4.7) \\
1.9(0.8-4.6) \\
1.7(0.6-4.3)\end{array}$ \\
\hline Residence & $\begin{array}{l}\text { Sanchi } \\
\text { Chutung } \\
\text { Potzu } \\
\text { Kaohsu } \\
\text { Makung } \\
\text { Huhsi } \\
\text { Paihsa }\end{array}$ & $\begin{array}{r}24 \\
70 \\
59 \\
36 \\
132 \\
49 \\
84\end{array}$ & $\begin{array}{l}33.3 \\
44.3 \\
47.5 \\
41.7 \\
34.2 \\
34.7 \\
41.7\end{array}$ & $\begin{array}{l}1.0 \\
1.2(0.7-2.2) \\
1.4(0.7-2.6) \\
1.1(0.5-2.3) \\
0.8(0.5-1.3) \\
0.8(0.4-1.6) \\
1.3(0.9-1.9)\end{array}$ \\
\hline $\begin{array}{l}\text { Time of collection } \\
\text { (months of year) }\end{array}$ & $\begin{array}{l}\text { March-May } \\
\text { June-August } \\
\text { September-November } \\
\text { December-February }\end{array}$ & $\begin{array}{r}190 \\
104 \\
101 \\
79\end{array}$ & $\begin{array}{l}36.8 \\
38.5 \\
41.6 \\
43.0\end{array}$ & $\begin{array}{l}1.0 \\
1.1(0.7-1.8) \\
1.2(0.7-2.0) \\
1.3(0.8-2.2)\end{array}$ \\
\hline
\end{tabular}

${ }^{\mathrm{a} C o n f i d e n c e ~ i n t e r v a l . ~}$

Table 2 Associations between the detection rate of $A F B_{1}$-albumin adducts and infection with hepatitis B and C viruses, habits of cigarette smoking and alcohol drinking, and genotypes of glutathione S-transferase (GST) MI-I and TI-I

\begin{tabular}{|c|c|c|c|c|}
\hline \multirow[b]{2}{*}{ Factors } & \multirow[b]{2}{*}{ Group } & \multirow[b]{2}{*}{ No. } & \multicolumn{2}{|c|}{$A F B_{1}$-albumin adducts } \\
\hline & & & $\begin{array}{c}\text { Detection } \\
\text { rate (\%) }\end{array}$ & $\begin{array}{l}\text { Odds ratio } \\
\left(95 \% \mathrm{Cl}^{\mathrm{a}}\right)\end{array}$ \\
\hline $\mathrm{HBsAg} g^{a}$ & $\begin{array}{l}\text { Negative } \\
\text { Positive }\end{array}$ & $\begin{array}{l}273 \\
201\end{array}$ & $\begin{array}{l}36.6 \\
42.8\end{array}$ & $\begin{array}{l}1.0 \\
1.3(1.0-1.9)\end{array}$ \\
\hline Anti-HCV ${ }^{a}$ & $\begin{array}{l}\text { Negative } \\
\text { Positive }\end{array}$ & $\begin{array}{r}406 \\
36\end{array}$ & $\begin{array}{l}41.6 \\
30.6\end{array}$ & $\begin{array}{l}1.0 \\
0.7(0.3-1.3)\end{array}$ \\
\hline Cigarette smoking & $\begin{array}{l}\text { Non-smoker } \\
\text { Smoker }\end{array}$ & $\begin{array}{l}248 \\
226\end{array}$ & $\begin{array}{l}35.1 \\
43.8\end{array}$ & $\begin{array}{l}1.0 \\
1.4(1.0-2.1)\end{array}$ \\
\hline Alcohol drinking & $\begin{array}{l}\text { Non-drinker } \\
\text { Drinker }\end{array}$ & $\begin{array}{r}394 \\
80\end{array}$ & $\begin{array}{l}39.9 \\
36.2\end{array}$ & $\begin{array}{l}1.0 \\
0.9(0.5-1.4)\end{array}$ \\
\hline GSTMI-I & $\begin{array}{l}\text { Non-null } \\
\text { Null }\end{array}$ & $\begin{array}{l}209 \\
193\end{array}$ & $\begin{array}{l}36.4 \\
43.0\end{array}$ & $\begin{array}{l}1.0 \\
1.3(1.0-1.9)\end{array}$ \\
\hline GSTTI-I & $\begin{array}{l}\text { Non-null } \\
\text { Null }\end{array}$ & $\begin{array}{l}234 \\
163\end{array}$ & $\begin{array}{l}35.9 \\
44.2\end{array}$ & $\begin{array}{l}1.0 \\
1.4(1.0-2.0)\end{array}$ \\
\hline
\end{tabular}

a $\mathrm{HBs} A$ g, hepatitis $\mathrm{B}$ surface antigen, anti-HCV , antibodies to hepatitis $\mathrm{C}$ virus; $\mathrm{Cl}$ confidence interval.

of the endogenous cytochrome P-450 enzyme superfamily (Guengerich et al, 1992; Gallagher et al, 1994). Based upon knowledge of $\mathrm{AFB}_{1}$ metabolism, a number of molecular dosimetry markers of aflatoxin exposure have been developed (Gan et al, 1988; Groopman et al, 1992; Yu et al, 1997). Among them the $\mathrm{AFB}_{1}$-albumin adduct has been a useful biomarker reflecting long-term exposure to aflatoxins in different populations (Gan et al, 1988; Wild et $a l, 1990$ ) and linking to an elevated risk of HCC (Chen et al, 1996a,b; Wang et al, 1996b; Sun et al, 2001). Thus, exploring the determinants of formation of $\mathrm{AFB}_{1}$-albumin adducts may contribute to understanding the complex interaction among multiple risk factors involved in hepatocarcinogenesis.

The major factors determining the formation of $\mathrm{AFB}_{1}$-albumin adducts for an individual in this population are gender and HBsAg
Table 3 The detection rate of $\mathrm{AFB}_{1}$-albumin adducts in relation to combined genotypes of glutathione S-transferase (GST) MI-I and TI-I by hepatitis B carrier status

\begin{tabular}{|c|c|c|c|c|c|}
\hline $\begin{array}{l}\text { HBsAg }^{\mathbf{a}} \\
\text { carrier } \\
\text { status }\end{array}$ & & GSTMI-I/TI-I & No. & $\begin{array}{c}\text { Detection } \\
\text { rate (\%) }\end{array}$ & $\begin{array}{l}\text { Odds ratio } \\
\left(95 \% \mathrm{Cl}^{\mathrm{a}}\right)\end{array}$ \\
\hline Non-carrier & Test for trend & $\begin{array}{l}\text { Both non-null } \\
\text { At least one null } \\
\text { Both null }\end{array}$ & $\begin{array}{r}59 \\
118 \\
49\end{array}$ & $\begin{array}{l}30.5 \\
36.4 \\
46.9\end{array}$ & $\begin{array}{l}1.0 \\
1.2(0.7-2.1) \\
1.8(0.9-3.8) \\
\quad P=0.142\end{array}$ \\
\hline Carrier & Test for trend & $\begin{array}{l}\text { Both non-null } \\
\text { At least one null } \\
\text { Both null }\end{array}$ & $\begin{array}{l}66 \\
72 \\
31\end{array}$ & $\begin{array}{l}36.4 \\
44.4 \\
51.6\end{array}$ & $\begin{array}{l}1.0 \\
1.3(0.7-2.3) \\
1.7(0.7-3.4) \\
\quad P=0.084\end{array}$ \\
\hline
\end{tabular}

${ }^{\mathrm{a}} \mathrm{HBsAg}$, hepatitis B surface antigen; $\mathrm{Cl}$, confidence interval.

Table 4 Logistic regression analysis of multiple factors associated with the detection rate of $A F B_{1}$-albumin adducts

\begin{tabular}{|c|c|c|}
\hline Variable & Group & Adjusted odds ratio $\left(95 \% \mathrm{Cl}^{\mathrm{a}}\right)$ \\
\hline Gender & $\begin{array}{l}\text { Female } \\
\text { Male }\end{array}$ & $\begin{array}{l}1.0 \\
2.6(1.4-5.0)\end{array}$ \\
\hline$A g e^{a}$ & & I.I $(0.8-1.4)$ \\
\hline $\mathrm{HBsAg} g^{b}$ & $\begin{array}{l}\text { Negative } \\
\text { Positive }\end{array}$ & $\begin{array}{l}1.0 \\
1.4(1.0-2.1)\end{array}$ \\
\hline Anti-HCV ${ }^{b}$ & $\begin{array}{l}\text { Negative } \\
\text { Positive }\end{array}$ & $\begin{array}{l}1.0 \\
0.7(0.3-1.5)\end{array}$ \\
\hline Cigarette smoking & $\begin{array}{l}\text { Non-smoker } \\
\text { Smoker }\end{array}$ & $\begin{array}{l}1.0 \\
1.2(0.8-1.8)\end{array}$ \\
\hline Alcohol drinking & $\begin{array}{l}\text { Non-drinker } \\
\text { Drinker }\end{array}$ & $\begin{array}{l}1.0 \\
0.7(0.4-1.1)\end{array}$ \\
\hline GSTMI- $1^{b}$ & $\begin{array}{l}\text { Non-null } \\
\text { Null }\end{array}$ & $\begin{array}{l}1.0 \\
1.3(0.8-1.8)\end{array}$ \\
\hline GSTT- $1^{b}$ & $\begin{array}{l}\text { Non-null } \\
\text { Null }\end{array}$ & $\begin{array}{l}1.0 \\
1.3(0.9-2.0)\end{array}$ \\
\hline
\end{tabular}

${ }^{a}$ Consecutive scores of $1,2,3$, and 4 were assigned to age groups of $30-39,40-49$ $50-59$, and 60-64 years, respectively. ${ }^{\mathrm{b}} \mathrm{HBsAg}$, hepatitis B surface antigen; anti$\mathrm{HCV}$, antibodies to hepatitis C virus; GSTMI-I, glutathione S-transferase MI-I: GSTTI-I, glutathione S-transferase TI-I; Cl, confidence interval.

carrier status. Males have significantly higher detectable adduct levels than females. This finding is in contrast to those observed in previous studies whether there was no significant association between gender and aflatoxin adduct levels (Wang et al, 1996a; Wild et al, 2000). The gender difference in detectable adduct levels might be attributable to differences in aflatoxin exposure or metabolism. It has been noted that HCC is $2-3$ times more frequent in males than in females in Taiwan, despite their similarity in HBsAg carrier status (Chen et al, 1997). The gender difference in the formation of $\mathrm{AFB}_{1}$-albumin adducts might contribute to the increased susceptibility to hepatocarcinogenesis in males.

In this study, there was moderately significant effect of $\mathrm{HBsAg}$ carrier status on detectable $\mathrm{AFB}_{1}$-albumin adduct levels. HBsAgpositive adults have higher detectable adduct levels than HBsAgnegative adults (42.8 vs 36.6\%). In particular, HBsAg-positive males have $50 \%$ higher frequency of detectable adducts than their HBsAg-negative counterpart (46.7 vs 39.5\%; adjusted OR=1.5, 95\% $\mathrm{CI}=1.1-2.4$; data not shown). The possible association between chronic HBV infection and the increased activation of $\mathrm{AFB}_{1}$ has been examined in epidemiological studies. Two studies of young Gambian children have reported higher $\mathrm{AFB}_{1}$-albumin adduct levels in HBsAg carriers than in non-carriers (Allen et al, 1992; 
Wild et al, 1993). Another study of adolescents in Taiwan has also found a higher $\mathrm{AFB}_{1}$-albumin adduct levels in $\mathrm{HBs} A g$-positive than negative subjects (Chen et al, 2001). Whereas, results from studies in adults are somewhat contradictory; in Guinea there was a nonsignificant increase in $\mathrm{AFB}_{1}$-albumin adducts in $\mathrm{HBs} A$-positive individuals (Diallo et al, 1995), while in China (Wang et al, 1996a) and Gambia (Wild et al, 2000) no such effect was observed. Furthermore, two recent studies of Chinese adult populations revealed that HBsAg positive status did not have significant effects on the temporal variability in $\mathrm{AFB}_{1}$-albumin adducts (Wang et al, 1996a; Ahsan et al, 2001). Therefore, we are left with apparent inconclusive results between studies in children and adults as well as between studies in adults in different populations regarding the effect of chronic $\mathrm{HBV}$ infection on $\mathrm{AFB}_{1}$-albumin adduct levels. In this study, a moderately significant difference in detectable $\mathrm{AFB}_{1}$ albumin adduct levels was found between HBsAg-positive and negative adults, particularly in males. This finding may result in part from the selection of study subjects from individuals who participated in a liver cancer screening programme. Those subjects may have viral-associated underlying subclinical liver diseases and may have a significant stimulation of the activation of $\mathrm{AFB}_{1}$, as indicated in previous studies (de Flora et al, 1985). Although it is known from experimental studies that liver injury associated with HBV can affect expression of carcinogen metabolizing enzymes (de Flora et al, 1989; Chemin et al, 1999), the biological mechanism that underlies the interaction between chronic HBV infection and increased activation of $\mathrm{AFB}_{1}$ in humans merit further studies.

Accumulating evidence indicates that genetic polymorphisms in $\mathrm{AFB}_{1}$ metabolising enzymes are a factor in individual susceptibility

\section{REFERENCES}

Ahsan H, Wang LY, Chen CJ, Tsai WY, Santella RM (2001) Variability in aflatoxin-albumin adduct levels and effects of hepatitis B and C virus infection and glutathione S-transferase M1 and T1 genotype. Environ Health Perspect 109: 833-837

Allen SJ, Wild CP, Wheeler JG, Riley EM, Montesano R, Bennett S, Whittle HC, Hall AJ, Greenwood BM (1992) Aflatoxin exposure, malaria and hepatitis B infection in rural Gambian children. Trans $R$ Soc Trop Med Hyg 86: $426-430$

Bell DA, Taylor JA, Paulson DF, Robertson CN, Mohler JL, Lucier GW (1993) Genetic risk and carcinogen exposure: a common inherited defect of the carcinogen-metabolism gene glutathione S-transferase M1 (GSTM1) that increases susceptibility to bladder cancer. J Natl Cancer Inst 85: 1159-1164

Chemin I, Ohgaki H, Chisari FV, Wild CP (1999) Altered expression of hepatic carcinogen metabolizing enzymes with liver injury in HBV transgenic mouse lineages expressing various amounts of hepatitis B surface antigen. Liver 19: $81-87$

Chen CJ, Liang KY, Chang AS, Chang YC, Lu SL, Liaw YF, Chang WY, Sheen MC (1991) Effects of hepatitis B virus, alcohol drinking, cigarette smoking and familial tendency on hepatocellular carcinoma. Hepatology 13: $398-$ 406

Chen CJ, Wang LY, Lu SN, Wu MH, You SL, Zhang YJ, Wang LW, Santella RM (1996a) Elevated aflatoxin exposure and increased risk of hepatocellular carcinoma. Hepatology 24: 38-42

Chen CJ, Yu MW, Liaw YF, Wang LW, Chiamprasert S, Matin F, Hirvonen A, Bell DA, Santella RM (1996b) Chronic hepatitis B carriers with null genotypes of glutathione S-transferase M1 and T1 polymorphisms who are exposed to aflatoxin are at increased risk of hepatocellular carcinoma. Am J Hum Genet 59: $128-134$

Chen CJ, Yu MW, Liaw YF (1997) Epidemiological characteristics and risk factors of hepatocellular carcinoma. J Gastroenterol Hepatol 12: S294-S308

Chen SY, Chen CJ, Chou SR, Hsieh LL, Wang LY, Tsai WY, Ahsan H, Santella RM (2001) Association of aflatoxin $B_{1}$-albumin adduct levels with hepatitis $\mathrm{B}$ surface antigen status among adolescents in Taiwan. Cancer Epidemiol Biomark Prev 10: $1223-1226$ to aflatoxin-induced hepatocarcinogenesis (McGlynn et al, 1995; Chen et al, 1996b; Sun et al, 2001). Members of the glutathione S-transferase (GST) family, such as GST- $\mu$ (GSTM1-1) and GST$\theta$ (GSTT1-1), are important candidates for involvement in susceptibility to aflatoxin-related liver cancer because they may regulate an individual's ability to metabolize the ultimate carcinogen of aflatoxins, the exo-epoxide (Johnson et al, 1997). The current study observed that the detection rate of $\mathrm{AFB}_{1}$-albumin adducts tended to increase as the number of null genotypes of GSTM1-1 and GSTT1-1 increased. This biological gradient was observed in both HBsAg carriers and non-carriers, albeit the trend was statistically non-significant.

In essence, our knowledge base about determinants of formation of $\mathrm{AFB}_{1}$ macromolecular adducts in humans is still limited. In this study, we have assessed the relative contributions of environmental determinants and host susceptibility factors in the formation of aflatoxin-albumin adducts in a well characterised Chinese adult population. The result of present study suggests that gender and HBsAg carrier status are major determinants of the formation of aflatoxin covalently bound to albumin. This study further emphasises the necessity to reduce aflatoxin exposure in people living in an area endemic for chronic HBV infection.

\section{ACKNOWLEDGEMENTS}

The work was supported by grants from Department of Health, Executive Yuan, Republic of China and US National Institutes of Health (ES05116 and P30ES09089).
De Flora S, Romano M, Basso C, Serra D, Astengo M, Picciotto A (1985) Metabolic activation of hepatocarcinogens in chronic hepatitis B. Mutation Res 144: $213-219$

De Flora S, Hietanen E, Bartsch H, Camoirano A, Izzotti A, Bagnasco M, Millman I (1989) Enhanced metabolic activation of chemical hepatocarcinogens in woodchucks infected with hepatitis B virus. Carcinogenesis 10: $1099-1106$

Diallo MS, Sylla A, Sidibe K, Sylla BS, Trepo CR, Wild CP (1995) Prevalence of exposure to aflatoxin and hepatitis B and C viruses in Guinea, West Africa. Nat Toxins 3: 6-9

Gallagher EP, Wienkers LC, Stapleton PL, Kunze KL, Eaton DL (1994) Role of human microsomal and human complementary DNA-expressed cytochromes P4501A2 and P4503A4 in the bioactivation of aflatoxin B1. Cancer Res 54: $101-108$

Gan LS, Skipper PL, Peng XC, Groopman JD, Chen JS, Wogan GN, Tannenbaum SR (1988) Serum albumin adducts in the molecular epidemiology of aflatoxin carcinogenesis: correlation with aflatoxin B1 intake and urinary excretion of aflatoxin M1. Carcinogenesis 9: 1323-1325

Groopman JD, Zhu JQ, Donahue PR, Pikul A, Zhang LS, Chen JS, Wogan GN (1992) Molecular dosimetry of urinary aflatoxin-DNA adducts in people living in Guangxi Autonomous Region, People's Republic of China. Cancer Res 52: 45-52

Guengerich FP, Shimada T, Raney KD, Yun CH, Meyer DJ, Ketterer B, Harris TM, Groopman JD, Kadlubar FF (1992) Elucidation of catalytic specificities of human cytochrome P450 and glutathione S-transferase enzymes and relevance to molecular epidemiology. Environ Health Perspect 98: 75-80

Guengerich FP, Johnson WW, Shimada T, Ueng YF, Yamazaki H, Langouet S (1998) Activation and detoxication of aflatoxin B1. Mutation Res 402: $121-128$

International Agency for Research on Cancer (1992) Evaluation of carcinogenic risks to humans. IARC Monographs 56: 245-395 
Johnson WW, Ueng YF, Widersten M, Mannervik B, Hayes JD, Sherratt PJ, Ketterer B, Guengerich FP (1997) Conjugation of highly reactive aflatoxin B1 exo-8,9-epoxide catalyzed by rat and human glutathione transferases: estimation of kinetic parameters. Biochemistry 36: 3056-3060

McGlynn KA, Rosvold EA, Lustbader ED, Hu Y, Clapper ML, Zhou T, Wild CP, Xia XL, Baffoe-Bonnie A, Ofori-Adjei D (1995) Susceptibility to hepatocellular carcinoma is associated with genetic variation in the enzymatic detoxification of aflatoxin B1. Proc Natl Acad Sci USA 92: 2384-2387

Pemble S, Schroeder KR, Spencer SR, Meyer DJ, Hallier E, Bolt HM, Ketterer B, Taylor JB (1994) Human glutathione S-transferase theta (GSTT1) cDNA cloning and the characterization of a genetic polymorphism. Biochem J 300: 271-276

Ross RK, Yuan JM, Yu MC, Wogan GN, Qian GS, Tu JT, Groopman JD, Gao YT, Henderson BE (1992) Urinary aflatoxin biomarkers and risk of hepatocellular carcinoma. Lancet 339: 943-946

Ryder RW, Whittle HC, Sanneh AB, Ajdukiewicz AB, Tulloch S, Yvonnet B (1992) Persistent hepatitis B virus infection and hepatoma in The Gambia, west Africa: a case-control study of 140 adults and their 603 family contacts. Am J Epidemiol 136: $1122-1131$

Sylla A, Diallo MS, Castegnaro J, Wild CP (1999) Interactions between hepatitis B virus infection and exposure to aflatoxins in the development of hepatocellular carcinoma: a molecular epidemiological approach. Mutation Res 428: $187-196$

Sun CA, Wang LY, Chen CJ, Lu SL, You SL, Wang LW, Wang Q, Wu DM, Santella RM (2001) Genetic polymorphisms of glutathione S-transferase M1 and T1 associated with susceptibility to aflatoxin-related hepatocarcinogenesis among chronic hepatitis B carriers: a nested case-control study in Taiwan. Carcinogenesis 22: 1289-1294
Wang JS, Qian GS, Zarba A, He X, Zhu YR, Zhang BC, Jacobson L, Gange SJ, Munoz A, Kensler TW (1996a) Temporal patterns of aflatoxin-albumin adducts in hepatitis B surface antigen-positive and antigen-negative residents of Daxin, Qidong County, People's Republic of China. Cancer Epidemiol Biomark Prev 5: 253-261

Wang LY, Hatch M, Chen CJ, Levin B, You SL, Lu SN, Wu MH, Wu WP, Wang LW, Wang Q, Huang GT, Yang PM, Lee HS, Santella RM (1996b) Aflatoxin exposure and risk of hepatocellular carcinoma in Taiwan. Int J Cancer 67: 620-625

Wild CP, Garner RC, Montesano R, Tursi F (1986) Aflatoxin B1 binding to plasma albumin and liver DNA upon chronic administration to rats. Carcinogenesis 7: $853-858$

Wild CP, Jiang YZ, Allen SJ, Jansen LA, Hall AJ, Montesano R (1990) Aflatoxin-albumin adducts in human sera from different regions of the world. Carcinogenesis 11: 2271-2274

Wild CP, Fortuin M, Donato F, Whittle HC, Hall AJ, Wolf CR, Montesano R (1993) Aflatoxin, liver enzymes, and hepatitis B virus infection in Gambian children. Cancer Epidemiol Biomark Prev 2: 555-561

Wild CP, Yin F, Turner PC, Chemin I, Chapot B, Mendy M, Whittle H, Kirk GD, Hall AJ (2000) Environmental and genetic determinants of aflatoxinalbumin adducts in the Gambia. Int J Cancer 86: 1-7

Yeh FS, Yu MC, Mo CC, Luo S, Tong MJ, Henderson BE (1989) Hepatitis B virus, aflatoxins, and hepatocellular carcinoma in southern Guangxi, China. Cancer Res 49: 2506-2509

Yu MW, Lien JP, Chiu YH, Santella RM, Liaw YF, Chen CJ (1997) Effect of aflatoxin metabolism and DNA adduct formation on hepatocellular carcinoma among chronic hepatitis B carriers in Taiwan. J Hepatol 27: 320 - 330 